\title{
Mechanisms of Sugar Transport in the Rumen Bacterium Selenomonas ruminantium
}

\author{
By SCOTT A. MARTIN ${ }^{*} \dagger$ AND JAMES B. RUSSELL $L^{1,2}$ \\ ${ }^{1}$ Department of Animal Science, Cornell University and ${ }^{2}$ Agricultural Research Service, \\ US Department of Agriculture, Ithaca, NY 14853, USA
}

(Received 16 July 1987; revised 25 September 1987)

\begin{abstract}
Toluene-treated cells of Selenomonas ruminantium HD4 used phosphoenolpyruvate (PEP) to phosphorylate glucose and sucrose. Glucose activity was constitutive, while the phosphorylation of sucrose was inducible. Competition experiments indicated that separate phosphotransferase (PTS) enzymes II were present for glucose and sucrose, but it appeared that maltose was hydrolysed by an inducible extracellular maltase and then transported by the glucose PTS. $S$. ruminantium HD4 grew more slowly on maltose than glucose or sucrose and the specific activity of maltase was rate limiting. The maltase was competitively inhibited by glucose and sucrose. Xylose was not phosphorylated by PEP or ATP, and its uptake was inhibited by the protonophore carbonyl cyanide $m$-chlorophenylhydrazone (CCCP), and by chlorhexidine diacetate. The absence of PEP-dependent phosphorylation and the effects of CCCP suggested that xylose was transported by an active transport mechanism.
\end{abstract}

\section{INTRODUCTION}

Selenomonas ruminantium is a Gram-negative anaerobe that was originally isolated from the rumen (Lessel \& Breed, 1954). Latham et al. (1971) determined that up to $16 \%$ of the total bacterial counts in the rumen were $S$. ruminantium. Recent work showed that this species accounted for more than $20 \%$ of the isolates from the caecal contents of pigs (Robinson et al., 1981). Many different carbohydrates are fermented by $S$. ruminantium, and it can grow under a variety of dietary conditions (Hungate, 1966). When it is grown in batch culture (high growth rate) with glucose, lactate is the predominant fermentation product (Hobson, 1965). Rapid growth and lactate production by $S$. ruminantium contributes to the acidity of rumen fluid, and it is more acid tolerant than many other rumen bacteria (Russell \& Dombrowski, 1980). After hexose is depleted, the bacterium then utilizes the lactate as an energy and carbon source. In this secondary fermentation, acetate and propionate are the primary products (Scheifinger et al., 1975; Russell \& Baldwin, 1978). S. ruminantium, however, has a low affinity for lactate (Russell \& Baldwin, 1979), and may not be a significant lactate utilizer in the rumen (Counotte et al., 1981).

Previous studies showed that $S$. ruminantium had high affinities for glucose, maltose, sucrose and xylose (Russell \& Baldwin, 1979), but glucose, sucrose and xylose were used in preference to maltose (Russell \& Baldwin, 1978). Glucose and sucrose caused an inhibition of maltose utilization and it appeared that catabolite regulatory mechanisms controlled maltose utilization (Russell \& Baldwin, 1978). Recent work (Martin \& Russell, 1986) showed that toluene-treated cells of $S$. ruminantium HD4 possessed PTS activity for glucose and 2-DG, but no information

† Present address: Animal and Dairy Science Department, Livestock-Poultry Building, University of Georgia, Athens, GA 30602, USA.

Abbreviations: CCCP, carbonyl cyanide m-chlorophenylhydrazone; 2-DG, 2-deoxy-D-glucose; PNPG, $p$-nitrophenyl $\alpha$-D-glucopyranoside; PEP, phosphoenolpyruvate; PTS, phosphotransferase system; p.m.f., protonmotive force. 
was available on the transport of other sugars. Since transport is the first step in sugar metabolism, and since uptake is often a key characteristic determining the success of bacteria in natural environments (Matin \& Veldkamp, 1978), we sought to examine how maltose, sucrose and xylose were translocated across the cell membrane.

\section{METHODS}

Organism and growth conditions. The HD4 strain of Selenomonas ruminantium was used (Bryant, 1956). Basal medium contained (1-1) (adjusted to pH 6.7): $\mathrm{K}_{2} \mathrm{HPO}_{4}, 292 \mathrm{mg} ; \mathrm{KH}_{2} \mathrm{PO}_{4}, 292 \mathrm{mg} ;\left(\mathrm{NH}_{4}\right)_{2} \mathrm{SO}_{4}, 480 \mathrm{mg} ; \mathrm{NaCl}$, $480 \mathrm{mg} ; \mathrm{MgSO}_{4} .7 \mathrm{H}_{2} \mathrm{O}, 100 \mathrm{mg} ; \mathrm{CaCl}_{2} .2 \mathrm{H}_{2} \mathrm{O}, 64 \mathrm{mg} ; \mathrm{Na}_{2} \mathrm{CO}_{3}, 4 \mathrm{~g} ;$ cysteine. $\mathrm{HCl}, 0.6 \mathrm{~g} ;$ Trypticase (BBL), $1 \mathrm{~g}$; resazurin, $1 \mathrm{mg}$; yeast extract, $0.5 \mathrm{~g}$; acetic acid, $1.7 \mathrm{~g}$; propionic acid, $0.6 \mathrm{~g}$; butyric acid, $0.3 \mathrm{~g}$; valeric, isovaleric, isobutyric and 2-methylbutyric acids, $(0.1 \mathrm{~g}$ each). Sugars were prepared as separate anaerobic solutions $(20 \%$, w/v) under $\mathrm{N}_{2}$ and added ( $6 \mathrm{~g}$ sugar $1^{-1}$ ) to the basal medium after autoclaving. Incubations were done anaerobically (under $\mathrm{CO}_{2}$ ) at $39^{\circ} \mathrm{C}$ in batch culture.

Spontaneous glucose-PTS-deficient mutants were selected for their resistance to the non-metabolizable glucose analogue 2-DG. Maltose- or sucrose-grown cells of $S$. ruminantium HD4 were inoculated into basal medium containing either $11 \mathrm{mM}$-maltose and $0.5 \mathrm{~mm}$-2-DG or $11 \mathrm{~mm}$-sucrose and $0.5 \mathrm{mM}-2-\mathrm{DG}$ and were incubated at $39^{\circ} \mathrm{C}$ for 3-7 d. The spontaneous mutants ( $S$. ruminantium HD4-S1 and HD4-S2) were isolated as previously described (Vadeboncoeur \& Trahan, 1982; Martin \& Russell, 1987); these cultures were repeatedly transferred in basal medium containing 2-DG.

Toluene-treated cells. Cells were harvested $(40 \mathrm{ml})$ during exponential growth (optical density at $600 \mathrm{~nm}$ approximately $1.0 ; 138 \mathrm{mg}$ cell protein $\left.1^{-1}\right)$ by centrifugation $\left(10000 \mathrm{~g}, 10 \mathrm{~min}, 4^{\circ} \mathrm{C}\right)$ and washed once with $100 \mathrm{mM}$-sodium/potassium phosphate buffer ( $50 \mathrm{mM}$-sodium phosphate, $50 \mathrm{~mm}$-potassium phosphate, $\mathrm{pH} 7 \cdot 2$ ) containing $5 \mathrm{mM}-\mathrm{MgCl}_{2}$. Cells were then suspended in $10 \mathrm{ml}$ of buffer $\left(553 \mu \mathrm{g}\right.$ cell protein $\left.\mathrm{ml}^{-1}\right)$ and stored on ice. Cell suspension $(1.0 \mathrm{ml})$ was treated with $30 \mu \mathrm{l}$ of toluene/ethanol mixture $(1: 9, \mathrm{v} / \mathrm{v})$ as previously described (Kornberg \& Reeves, 1972; Martin \& Russell, 1986).

Sonicated cell extracts. Cells were harvested $(400 \mathrm{ml})$ and washed as described above. The cells were suspended in $4 \mathrm{ml}$ of buffer and sonicated for $2 \mathrm{~min}$ (Branson model 200 Sonifier; microtip, 30\% duty cycle, $4^{\circ} \mathrm{C}$ ). Unbroken cells were removed by centrifugation $\left(37000 \mathrm{~g}, 20 \mathrm{~min}, 4^{\circ} \mathrm{C}\right)$, and the cell extract was stored on ice.

Cell-free extracts and membrane preparation. Maltose-grown cells from $400 \mathrm{ml}$ of culture were harvested and washed once in buffer containing $1 \mathrm{~mm}$-dithiothreitol. The cells were suspended in $4 \mathrm{ml}$ of buffer and broken in a French pressure cell ( $140 \mathrm{MPa}, 4^{\circ} \mathrm{C}$; SLM Instruments). The cell extract was then centrifuged at low speed $\left(5000 \mathrm{~g}, 10 \mathrm{~min}, 4^{\circ} \mathrm{C}\right)$ to remove any unbroken cells, and the resulting supernatant was centrifuged at high speed $\left(200000 \mathrm{~g}, 2 \mathrm{~h}, 4^{\circ} \mathrm{C}\right)$ to sediment membrane fragments. The pellet (membrane fraction) was resuspended in $4 \mathrm{ml}$ of buffer. Both the membrane and cytoplasmic fractions were stored at $-20^{\circ} \mathrm{C}$ overnight. No significant loss of enzyme activity was observed under these storage conditions.

Phosphorylation assays. PEP-dependent sugar phosphorylation was measured with radiolabelled sugars and this activity was compared to that observed with ATP (Gachelin, 1970; Vadeboncoeur et al., 1983; Martin \& Russell, 1986). The reaction mixture $(1.0 \mathrm{ml})$ contained $100 \mathrm{~mm}$-sodium/potassium phosphate buffer $(\mathrm{pH} \mathrm{7.2)}, 5 \mathrm{mM}$ $\mathrm{MgCl}_{2}, 1 \mathrm{mM}$-dithiothreitol, $10 \mathrm{mM}$-PEP or $10 \mathrm{mM}-\mathrm{ATP}$, and $100 \mu \mathrm{l}$ of toluene-treated cells (final concentration $48 \mu \mathrm{g}$ protein $\left.\mathrm{ml}^{-1}\right)$. The reaction was started by the addition of $1 \mathrm{mM}$ of sugar that contained $0 \cdot 2 \mu \mathrm{Ci}(7 \cdot 4 \mathrm{kBq}), \mathrm{D}-$ $\left[\mathrm{U}-{ }^{14} \mathrm{C}\right]$ glucose, $\left[\mathrm{U}-{ }^{14} \mathrm{C}\right]$ maltose, $\left[\mathrm{U}-{ }^{14} \mathrm{C}\right]$ sucrose or $\mathrm{D}-\left[\mathrm{U}-{ }^{14} \mathrm{C}\right] x y l o s e$. After incubation at $39^{\circ} \mathrm{C}$ for $30 \mathrm{~min}$, the phosphorylated product was precipitated with $10 \mathrm{ml} \mathrm{BaBr}_{2}$ solution $\left(30 \mathrm{mM}\right.$ in $90 \%$, v/v, ethanol; $\left.20 \mathrm{~min}, 0^{\circ} \mathrm{C}\right)$. The precipitates were then collected on $0.45 \mu \mathrm{m}$ pore size membrane filters (Millipore) and rinsed with $80 \%(\mathrm{v} / \mathrm{v})$ ethanol. The filters were air-dried and counted in a Packard Tri-Carb B2450 scintillation counter. The effect of Tris buffer on PTS activity in toluene-treated cells was also examined. Endogenous phosphorylation was estimated from controls lacking PEP or ATP, and these values were subtracted. All incubations and assays were done in triplicate, and variance is indicated by SD values.

Uptake by intact cells. ${ }^{14} \mathrm{C}$-labelled sugar uptake was examined in cells that were harvested $(40 \mathrm{ml})$ anaerobically and washed once with $\mathrm{O}_{2}$-free sodium/potassium phosphate buffer (100 mM, pH 7.2) plus $5 \mathrm{mM}-\mathrm{MgCl}_{2}$. The cells $\left(100 \mu \mathrm{l}\right.$ in $1 \mathrm{ml} ; 54.3 \mu \mathrm{g}$ cell protein $\left.\mathrm{ml}^{-1}\right)$ were preincubated in buffer or buffer plus inhibitor for $3 \mathrm{~min}$, and the reaction was started by adding $1 \mathrm{mM}$ sugar that contained $0.2 \mu \mathrm{Ci}(7 \cdot 4 \mathrm{kBq}) \mathrm{D}-\left[\mathrm{U}-{ }^{14} \mathrm{C}\right] \mathrm{glucose},\left[\mathrm{U}-{ }^{14} \mathrm{C}\right] \mathrm{maltose}$, [U${ }^{14} \mathrm{C}$ ]sucrose or $\mathrm{D}-\left[\mathrm{U}-{ }^{14} \mathrm{C}\right] \mathrm{xylose}$ as above. After incubation at $39^{\circ} \mathrm{C}$ for $12 \mathrm{~min}$, the reaction was stopped by placing the reaction tubes in an ice-bath and adding $5 \mathrm{ml}$ of ice-cold buffer. The cells were collected by filtration through $0.45 \mu \mathrm{m}$ pore size membrane filters and rinsed with $3 \mathrm{ml}$ of buffer. The filters were air-dried and counted as described above. The metabolic inhibitors CCCP (final concentration $20 \mu \mathrm{M}$ ) and chlorhexidine diacetate (final concentration $0.2 \mathrm{mM}$ ) were prepared in $2 \%(\mathrm{v} / \mathrm{v})$ ethanol, and the final concentration of ethanol added to each reaction mixture was $0.1 \%$. Control incubations contained the same final concentration $(0.1 \%)$ of ethanol. All incubations and assays were done in triplicate in a Coy anaerobic (under $\mathrm{CO}_{2}$ ) glove box. 
Maltose hydrolase assay. The hydrolysis of maltose to glucose was determined by an enzyme-coupled assay. The reaction mixture $(1.0 \mathrm{ml})$ contained $100 \mathrm{mM}$-sodium/potassium phosphate buffer $(\mathrm{pH} 7 \cdot 2), 5 \mathrm{mM}-\mathrm{MgCl}_{2}, 10 \mathrm{mM}-$ ATP, 4 mM-maltose, 0.8 mM-NADP+, 6.4 U glucose-6-phosphate dehydrogenase (EC 1.1.1.49), 2 U hexokinase (EC 2.7.1.1), and $100 \mu \mathrm{l}$ of cell extract $\left(52.2 \mu \mathrm{g}\right.$ protein $\left.\mathrm{ml}^{-1}\right)$, cell-free extract $\left(125 \mu \mathrm{g}\right.$ protein $\left.\mathrm{ml}^{-1}\right)$ or membrane protein $\left(245 \mu \mathrm{g} \mathrm{ml}^{-1}\right)$. Maltase (EC 3.2.1.20) activity was also measured continuously as the hydrolysis of PNPG at $400 \mathrm{~nm}$. The reaction mixture $(3.0 \mathrm{ml})$ contained $100 \mathrm{mM}$-potassium phosphate buffer $(\mathrm{pH} 7.0), 4 \mathrm{mM}$-PNPG and $100 \mu \mathrm{l}$ of cell extract (final concentration of protein $175 \mu \mathrm{g} \mathrm{ml}^{-1}$ ). Initial rates of PNPG hydrolysis were calculated using the molar extinction coefficient for $p$-nitrophenol $\left(10718 \mathrm{M}^{-1} \mathrm{~cm}^{-1}, \mathrm{pH} 7 \cdot 15\right.$; Kesters-Hilderson et al., 1982).

Sucrose hydrolase assay. Sucrose hydrolysis was determined by the enzymic method of St Martin \& Wittenberger (1979). Each $1.0 \mathrm{ml}$ reaction mixture contained $100 \mathrm{Mm}$-sodium/potassium phosphate buffer (pH 7.2), $5 \mathrm{mM}$ $\mathrm{MgCl}_{2}, 10 \mathrm{~mm}-\mathrm{ATP}, \quad 0.2 \mathrm{~mm}-\mathrm{NADP}^{+}, 6.4 \mathrm{U}$ glucose-6-phosphate dehydrogenase, $2 \mathrm{U}$ hexokinase, $2 \mathrm{U}$ phosphoglucose isomerase (EC 5.3.1.9), $4 \mathrm{mM}$-sucrose and $100 \mu \mathrm{l}$ of cell extract (final concentration of protein $585 \mu \mathrm{g} \mathrm{m}^{-1}$ ). The inhibitory effect of $20 \mathrm{mM}$-Tris buffer on maltose and sucrose hydrolysis was also examined.

Identification of extracellular sugars. Maltose-grown cells $(40 \mathrm{ml})$ were harvested anaerobically, washed once with $\mathrm{O}_{2}$-free $100 \mathrm{~mm}$-sodium/potassium phosphate buffer $(\mathrm{pH} 7 \cdot 2)$ plus $5 \mathrm{mM}-\mathrm{MgCl}_{2}$, and resuspended in $10 \mathrm{ml}$. Aliquots $\left(100 \mu \mathrm{l} ; 54.3 \mu \mathrm{g} \mathrm{ml}^{-1}\right)$ were added to a $1.0 \mathrm{ml}$ reaction mixture that contained the same buffer plus $5 \mathrm{mM}$ $\mathrm{MgCl}_{2}, 0.2 \mathrm{mM}$-chlorhexidine diacetate and $1 \mathrm{mM}$-maltose $\left(0 \cdot 2 \mu \mathrm{Ci}\right.$ [U- $\left.\left.{ }^{14} \mathrm{C}\right] \mathrm{maltose}\right)$. After incubation at $39^{\circ} \mathrm{C}$ for $30 \mathrm{~min}$, the cells were removed by centrifugation $(10000 \mathrm{~g}, 5 \mathrm{~min})$ and the supernatant was saved. All assays and incubations were done anaerobically under $\mathrm{CO}_{2}$. Reaction samples $(10 \mu \mathrm{l})$ were applied to a cellulose thin layer chromatogram, which was developed in a butyl alcohol/pyridine/water $(6: 4: 3$, by vol.) solvent system. Radioactive areas were qualitatively visualized by autoradiography and identified by co-chromatography with ${ }^{14} \mathrm{C}$-labelled glucose and maltose. $R_{F}$ values (relative to the solvent front) were 0.52 for maltose and 0.64 for glucose.

Protein determination. Protein content was determined by the Lowry method or according to Bradford (1976). All samples were treated with $0.2 \mathrm{M}-\mathrm{NaOH}\left(100^{\circ} \mathrm{C}, 15 \mathrm{~min}\right)$ and compared with a bovine serum albumin standard.

Chemicals. ATP, PEP, Tris, CCCP, chlorhexidine diacetate, PNPG, 2-DG, glucose, maltose, sucrose, xylose, dithiothreitol, $\mathrm{BaBr}_{2}, \mathrm{NADP}^{+}$, glucose-6-phosphate dehydrogenase, hexokinase and phosphoglucose isomerase were from Sigma. All other chemicals were of the highest purity commercially available. [U- $\left.{ }^{14} \mathrm{C}\right] \mathrm{Maltose}$, [U$\left.{ }^{14} \mathrm{C}\right]$ sucrose, and D-[U- $\left.{ }^{14} \mathrm{C}\right]$ xylose were obtained from Amersham. D- $\left[\mathrm{U}-{ }^{14} \mathrm{C}\right] \mathrm{Glucose}$ was purchased from New England Nuclear.

\section{RESULTS}

\section{Phosphorylation of sugars}

PTS activity was examined in toluene-treated cells of $S$. ruminantium HD4 by measuring the PEP-dependent phosphorylation of radiolabelled glucose, maltose, sucrose and xylose (Table 1). Glucose phosphorylation was observed even if the cells were grown on other sugars, but the maltose and sucrose activities were low unless the organism was grown on the same sugar. Sucrose was also phosphorylated by maltose-grown cells, but at approximately one-third the rate for maltose. No PTS activity was detected for xylose. Cells grown on maltose or xylose had the lowest maximum specific growth rates.

ATP-dependent $\left[{ }^{14} \mathrm{C}\right]$ glucose phosphorylation in toluene-treated cells is characteristic of glucokinase or hexokinase activity (Romano et al., 1979), and recent work showed that $S$. ruminantium HD4 had a glucokinase rather than a hexokinase (Martin \& Russell, 1986). Glucokinase activity was observed if the cells were grown on sugars other than glucose (Table 2), but glucose- and xylose-grown cells were unable to hydrolyse maltose or sucrose and phosphorylate the resulting monomers. Maltose-grown cells incubated with maltose phosphorylated sugar at less than half the rate of glucose, and ATP-dependent phosphorylation of $\left[{ }^{14} \mathrm{C}\right]$ sucrose was less than one-tenth the glucose rate even if the cells were grown on sucrose. These results indicated that inducible hydrolases were present for maltose and sucrose. Phosphorylation of $\left[{ }^{14} \mathrm{C}\right]$ xylose by ATP was never significant.

\section{Maltose and sucrose hydrolysis}

Cell extracts from maltose-grown cells had significant levels of maltase activity (Table 3), but sucrose was only hydrolysed at approximately one-tenth of this rate. Addition of $20 \mathrm{~mm}$-Tris buffer, a disaccharidase inhibitor (Dahlqvist, 1964; Groleau \& Forsberg, 1981), decreased 
Table 1. Effect of sugars on growth rate and the specific activity of PEP-dependent sugar phosphorylation by toluene-treated cells of $S$. ruminantium HD4

$\begin{array}{lcrrrr}\begin{array}{c}\text { Growth } \\ \text { substrate }\end{array} & \begin{array}{c}\mu^{*} \\ \left(\mathrm{~h}^{-1}\right)\end{array} & \text { Glucose } & \text { Maltose } & \text { Sucrose } & \text { Xylose } \\ \text { Glucose } & 0.66 & 104 \pm 30 & 8 \pm 0 & 7 \pm 1 & 2 \pm 0 \\ \text { Maltose } & 0.51 & 170 \pm 24 & 73 \pm 7 & 24 \pm 4 & 3 \pm 1 \\ \text { Sucrose } & 0.76 & 77 \pm 21 & 10 \pm 1 & 33 \pm 9 & 2 \pm 0 \\ \text { Xylose } & 0.53 & 49 \pm 4 & 8 \pm 2 & 8 \pm 1 & 3 \pm 1\end{array}$

* Maximum specific growth rate.

$\dagger$ nmol phosphorylated (mg protein) ${ }^{-1} \mathrm{~min}^{-1}$. The reaction mixture was incubated at $39^{\circ} \mathrm{C}$ for $30 \mathrm{~min}$

Table 2. Effect of the sugar supporting growth on the specific activity of ATP-dependent (kinase) sugar phosphorylation by toluene-treated cells of $S$. ruminantium HD4

\begin{tabular}{lcccc} 
Growth & \multicolumn{4}{c}{ Sugar phosphorylated* } \\
substrate & Glucose & Maltose & Sucrose & Xylose \\
Glucose & $141 \pm 23$ & $5 \pm 1$ & $3 \pm 0$ & $1 \pm 0$ \\
Maltose & $138 \pm 25$ & $50 \pm 8$ & $6 \pm 1$ & $2 \pm 1$ \\
Sucrose & $156 \pm 17$ & $4 \pm 1$ & $12 \pm 1$ & $1 \pm 0$ \\
Xylose & $63 \pm 2$ & $2 \pm 1$ & $4 \pm 1$ & $2 \pm 1$
\end{tabular}

* nmol phosphorylated (mg protein) $)^{-1} \mathrm{~min}^{-1}$. The reaction mixture was incubated at $39^{\circ} \mathrm{C}$ for $30 \mathrm{~min}$.

Table 3. Effect of maltose, sucrose and Tris buffer on maltose and sucrose hydrolase activity in cell extracts from maltose- and sucrose-grown cells

\begin{tabular}{|c|c|c|}
\hline $\begin{array}{l}\text { Growth } \\
\text { substrate }\end{array}$ & Addition & $\begin{array}{l}\text { Hydrolase } \\
\text { activity* }\end{array}$ \\
\hline Maltose & $\begin{array}{l}\text { Maltose } \\
\text { Sucrose } \\
\text { Maltose }+20 \mathrm{mM} \text {-Tris } \dagger\end{array}$ & $\begin{array}{r}488 \\
53 \\
86\end{array}$ \\
\hline Sucrose & $\begin{array}{l}\text { Sucrose } \\
\text { Maltose } \\
\text { Sucrose + } 20 \mathrm{mM} \text {-Tris } \dagger\end{array}$ & $\begin{array}{r}59 \\
7 \\
35\end{array}$ \\
\hline
\end{tabular}

maltose hydrolysis by $82 \%$. If the cell extract was divided into cytoplasmic and membrane fractions by high speed centrifugation, a greater proportion of the specific activity was found in the cytoplasmic fraction than the membrane fraction $\left[223\right.$ and $108 \mathrm{nmol}\left(\mathrm{mg}\right.$ protein) ${ }^{-1} \mathrm{~min}^{-1}$, respectively]. However, in terms of total activity, maltase was evenly distributed between the two fractions. The apparent $K_{\mathrm{m}}$ for maltose hydrolysis, as determined from Lineweaver-Burk plots, was $1.7 \mathrm{~mm}$ with a $V_{\max }$ of $658 \mathrm{nmol}(\mathrm{mg} \text { protein) })^{-1} \mathrm{~min}^{-1}$. The $K_{\mathrm{m}}$ for PNPG, a maltose analogue, was $2.5 \mathrm{~mm}$ and the $V_{\max }$ was $152 \mathrm{nmol}$ (mg protein) ${ }^{-1} \mathrm{~min}^{-1}$. Glucose and sucrose were competitive inhibitors of PNPG hydrolysis with $K_{\mathrm{i}}$ of $8.7 \mathrm{mM}$ for glucose and $17.4 \mathrm{~mm}$ for sucrose.

Cell extracts from sucrose-grown cells also hydrolysed sucrose and maltose, but these activities were low (Table 3) and consistent with the low rates of ATP-dependent phosphorylation (Table 2). Tris buffer inhibited sucrose hydrolysis by $41 \%$. The apparent $K_{\mathrm{m}}$ for sucrose hydrolysis was $2.3 \mathrm{mM}$ with a $V_{\max }$ of $78 \mathrm{nmol}(\mathrm{mg} \text { protein) })^{-1} \mathrm{~min}^{-1}$. 
Table 4. Effect of unlabelled sugars and Tris buffer on the PEP-dependent phosphorylation of ${ }^{14} \mathrm{C}$-labelled sugars by toluene-treated cells of S. ruminantium HD4

Reaction mixtures contained $100 \mathrm{~mm}$-sodium/potassium phosphate buffer (pH 7.2), $5 \mathrm{mM}-\mathrm{MgCl}_{2}$, $10 \mathrm{mM}-\mathrm{PEP}, 0$ or $10 \mathrm{~mm}$ unlabelled competing sugars or $0.2 \mathrm{mM}$-Tris buffer, $1 \mathrm{~mm}$ sugar that contained $0.2 \mu \mathrm{Ci}^{14} \mathrm{C}$-labelled sugars and $100 \mu \mathrm{l}$ of toluene-treated cells $\left(48 \mu \mathrm{g}\right.$ protein $\left.\mathrm{ml}^{-1}\right)$. Competing sugars or Tris buffer were added to the reaction mixture before the radiolabelled substrates. The reaction mixture was incubated at $39^{\circ} \mathrm{C}$ for $30 \mathrm{~min}$.

\begin{tabular}{lcccc} 
Radiolabelled & \multicolumn{4}{c}{ Percentage inhibition of phosphorylation by: } \\
\cline { 2 - 3 } & $\overbrace{\text { Glucose }}$ & Maltose & Sucrose & Tris \\
Glucose & 85 & 8 & 6 & 0 \\
Maltose & 68 & 79 & 29 & 49 \\
Sucrose & 35 & 18 & 77 & 0
\end{tabular}

* Cells grown on the same but unlabelled sugar.

Table 5. Effect of maltose or sucrose on the maximum specific growth rates and PTS specific activities for glucose and maltose in toluene-treated cells of S. ruminantium HD4, HD4-SI or HD4-S2

\begin{tabular}{|c|c|c|c|c|c|}
\hline \multirow[b]{2}{*}{ Organism } & \multirow[b]{2}{*}{ Substrate } & \multirow{2}{*}{$\begin{array}{c}\mu^{*} \\
\left(h^{-1}\right)\end{array}$} & \multicolumn{3}{|c|}{ PTS specific activity $\dagger$} \\
\hline & & & Glucose & Maltose & Sucrose \\
\hline S. ruminantium HD4 & Maltose & 0.51 & $170 \pm 24$ & $73 \pm 7$ & ND \\
\hline S. ruminantium HD4-S1 & Maltose & 0.21 & $34 \pm 5$ & $11 \pm 3$ & ND \\
\hline S. ruminantium HD4 & Sucrose & 0.76 & $77 \pm 21$ & ND & $33 \pm 9$ \\
\hline S. ruminantium HD4-S2 & Sucrose & 0.66 & $22 \pm 2$ & ND & $28 \pm 6$ \\
\hline
\end{tabular}

\section{Competition experiments}

To determine whether glucose, maltose and sucrose were transported by the same or different components of the PTS, a series of competition experiments was done (Table 4). In these experiments, a ${ }^{14} \mathrm{C}$-labelled sugar was incubated with a large excess $(10 \mathrm{~mm})$ of unlabelled sugar. Maltose and sucrose contained less than $0 \cdot 26 \%$ glucose, and unlabelled maltose or sucrose were unable to significantly inhibit $\left[{ }^{14} \mathrm{C}\right] \mathrm{glucose}$ phosphorylation. Unlabelled glucose inhibited the phosphorylation of $\left[{ }^{14} \mathrm{C}\right] \mathrm{glucose}$ by $85 \%$ and this inhibition was close to the theoretical dilution $(91 \%) .\left[{ }^{14} \mathrm{C}\right]$ Maltose and $\left[{ }^{14} \mathrm{C}\right]$ sucrose phosphorylation was also inhibited by unlabelled glucose. Maltose strongly inhibited $\left[{ }^{14} \mathrm{C}\right]$ maltose phosphorylation, but $\left[{ }^{14} \mathrm{C}\right]$ sucrose phosphorylation was also inhibited by $18 \%$. Phosphorylation of $\left[{ }^{14} \mathrm{C}\right]$ sucrose or $\left[{ }^{14} \mathrm{C}\right]$ maltose was inhibited by sucrose, but $\left[{ }^{14} \mathrm{C}\right] g l u c o s e$ phosphorylation was unaffected. Tris buffer only inhibited the PEPdependent phosphorylation of $\left[{ }^{14} \mathrm{C}\right]$ maltose.

\section{Phosphorylation by PTS mutants}

Since maltose and sucrose were phosphorylated by ATP as well as PEP (Tables 1 and 2), we examined disaccharide phosphorylation with glucose-PTS-deficient mutants (Table 5). When $S$. ruminantium HD4 and HD4-S1 were grown on maltose, the growth rate of the mutant (HD4-S1) was decreased by $60 \%$ and PEP-dependent phosphorylation of glucose and maltose were both decreased by approximately $80 \%$. S. ruminantium HD4-S2, another glucose-PTS-deficient mutant, and the wild-type had similar growth rates on sucrose and similar sucrose PTS activity even though glucose phosphorylation was reduced by $71 \%$. 


\section{Extracellular hydrolysis of disaccharides}

Since significant maltase activity was observed with membrane fractions, it seemed likely that maltose was hydrolysed to glucose extracellularly. When maltose-grown cells were incubated in the presence of $\left[{ }^{14} \mathrm{C}\right]$ maltose and chlorhexidine diacetate, a compound that inhibited the uptake of all sugars by approximately $90 \%$ (data not shown), extracellular $\left[{ }^{14} \mathrm{C}\right]$ glucose was detected by TLC. This qualitátive analysis indicated that maltose was indeed hydrolysed extracellularly, and that the resulting glucose monomers were available for transport into the cell as glucose.

\section{Xylose transport}

The lack of PTS activity for xylose suggested that a p.m.f. could be involved in transport. Therefore, we measured the effect of the protonophore CCCP $(20 \mu \mathrm{M})$ on $\left[{ }^{14} \mathrm{C}\right] x y$ lose uptake by intact cells. Uptake [ $\left.44 \mathrm{nmol}(\mathrm{mg} \text { protein })^{-1} \mathrm{~min}^{-1}\right]$ was inhibited by $83 \%$. This indicated that transmembrane proton gradients may be involved in the transport process. Chlorhexidine diacetate $(0 \cdot 2 \mathrm{mM})$ was also a strong inhibitor of $\left[{ }^{14} \mathrm{C}\right]$ xylose uptake $(95 \%)$.

\section{DISCUSSION}

Generally, anaerobic micro-organisms obtain low yields of ATP and the phosphoenolpyruvate:carbohydrate PTS is advantageous because transport and phosphorylation occur simultaneously and require less energy than active transport and kinase reactions (Postma \& Lengeler, 1985). PEP-dependent phosphorylation of a sugar is commonly used to determine if a micro-organism possesses PTS activity. Because bacterial cells utilizing the PTS often contain ATP-dependent glucokinase activity, the non-metabolizable sugar 2-DG is often used to verify the presence of a glucose PTS. Most bacterial glucokinases are unable to phosphorylate 2-DG, but $S$. ruminantium possesses an ATP-dependent 2-DG kinase (Martin \& Russell, 1986). The presence of this latter enzyme confounded the differentiation of ATP- and PEP-dependent mechanisms. However, the PEP-dependent activity was primarily associated with the membrane fraction and little PEP-dependent phosphorylation of glucose could be detected in cell-free extracts (Martin \& Russell, 1986). These latter observations indicated that PEPdependent phosphorylation of sugars was indicative of the PTS in this organism. In these experiments PEP-dependent phosphorylation of glucose was constitutive, while the phosphorylations of maltose and sucrose were inducible (Table 1). PTS-mediated transport of disaccharides ( $\beta$-glucosides, lactose, sucrose) has been described in enteric bacteria (Postma \& Lengeler, 1985), and an inducible maltose PTS has been observed in streptococci (St Martin \& Wittenberger, 1979; Martin \& Russell, 1987).

Even though PEP-dependent phosphorylation could be demonstrated when $\left[{ }^{14} \mathrm{C}\right]$ maltose was the substrate, the presence of a specific maltose PTS in S. ruminantium HD4 was not assured. Maltose could have been hydrolysed by an inducible maltase (Tables 2 and 3 ) and the resulting glucose monomers subsequently transported by the constitutive glucose PTS. Evidence supporting this mechanism was obtained from several observations: (i) much of the maltase was associated with the membrane fraction, and the appearance of extracellular glucose indicated that at least some of this activity was extracellular; (ii) Tris buffer significantly inhibited maltase activity (Table 3), and this compound also inhibited PEP-dependent sugar phosphorylation when $\left[{ }^{14} \mathrm{C}\right]$ maltose was provided (Table 4); (iii) unlabelled glucose inhibited PEP-dependent sugar phosphorylation resulting from $\left[{ }^{14} \mathrm{C}\right]$ maltose by $68 \%$, but unlabelled maltose (maltase not induced) only inhibited [ $\left.{ }^{14} \mathrm{C}\right]$ glucose phosphorylation by $8 \%$ (Table 4); (iv) a glucose-PTSdeficient mutant grew much more slowly on maltose and PEP-dependent phosphorylation of maltose was decreased to the same extent as glucose (Table 5); (v) the maximum specific growth rate on maltose was $23 \%$ less than the rate on glucose (Table 1), PEP-dependent phosphorylation of maltose was $29 \%$ less than the rate of glucose phosphorylation (Table 1), and maltase activity appeared to be a rate-limiting step in maltose utilization. Since maltose was hydrolysed extracellularly by an inducible hydrolase, and since significant PEP-dependent maltose phosphorylation could not be demonstrated if the glucose PTS was lacking, it is unlikely that maltose was taken up by a separate and inducible maltose PTS. 
Glucokinases and hexokinases are unable to phosphorylate disaccharides directly (Barman, 1969). The inducible ATP-dependent sucrose phosphorylation observed (Table 2) must therefore have been due to a sucrose hydrolase (Table 3). The rate of sucrose hydrolysis was much less than the activity observed for maltose, and Tris buffer was much less inhibitory $(41 \%)$. Because a sucrose hydrolase was present, sucrose could have also been hydrolysed extracellularly and transported as hexose. However, a glucose-PTS-deficient mutant ( $S$. ruminantium HD4-S2) grew rapidly on sucrose and was still able to phosphorylate sucrose (Table 5). Even though Tris buffer inhibited sucrose hydrolysis in cell extracts (Table 3), no inhibition of PEP-dependent sucrose phosphorylation was observed in toluene-treated cells (Table 4). These results indicated that little sucrose was hydrolysed extracellularly and subsequently transported by the glucose PTS.

Low rates of PEP-dependent sucrose phosphorylation by maltose-grown cells (Table 1) could be explained by maltase-mediated hydrolysis of sucrose (Table 3). Maltases from a variety of organisms have been shown to hydrolyse sucrose in addition to maltose (Barman, 1969). Because sucrose did not induce high levels of maltase activity (Table 3), PEP-dependent sucrose phosphorylation by sucrose-grown cells could not be explained by maltase-mediated hydrolysis of sucrose and subsequent transport by the glucose PTS.

Earlier work with $S$. ruminantium HD4 showed that maltose utilization is inhibited by the addition of glucose or sucrose (Russell \& Baldwin, 1978). When maltose-grown cells were incubated with [ $\left.{ }^{14} \mathrm{C}\right]$ maltose, a 10 -fold excess of glucose caused a $68 \%$ inhibition of PEPdependent $\left[{ }^{14} \mathrm{C}\right]$ maltose phosphorylation, but a 10 -fold excess of sucrose caused only a $29 \%$ inhibition of phosphorylation (Table 4). Since maltose was hydrolysed extracellularly, it seemed likely that glucose was regulating the maltase as well as competing for the glucose PTS. Neither glucose nor sucrose repressed maltase synthesis (data not shown), but both sugars competitively inhibited the hydrolysis of PNPG (a maltose analogue). The $K_{\mathrm{i}}$ for glucose $(8.7 \mathrm{mM}$ ) was $50 \%$ of the $K_{\mathrm{i}}$ for sucrose $(17.4 \mathrm{mM})$, and in toluene-treated cells, glucose inhibited [ $\left.{ }^{14} \mathrm{C}\right] \mathrm{maltose}$ phosphorylation more than sucrose did (Table 4). These results are consistent with the differences in $K_{\mathrm{i}}$. While the inhibition constants were rather high it should be noted that the $V_{\max }$ for PNPG hydrolysis was approximately one-fifth that for maltose. Since $K_{\mathrm{i}}$ is inversely proportional to $V_{\max }$ (Segel, 1976), the $K_{\mathrm{i}}$ for maltose inhibition may be less.

Unlabelled glucose inhibited $\left[{ }^{14} \mathrm{C}\right]$ sucrose phosphorylation to a greater extent than maltose did $(35 \%$ versus $18 \%)$, but the presence of an extracellular maltase meant that glucose could have been responsible in either case (Table 4). Since unlabelled sucrose did not significantly inhibit $\left[{ }^{14} \mathrm{C}\right]$ glucose phosphorylation, and since a glucose-PTS-deficient mutant was still able to phosphorylate sucrose (Table 5), it is unlikely that glucose and sucrose were transported by the same enzyme II. The presence of separate PTSs infers some specificity, but competition of different PTS sugars for non-sugar-specific components of the PTS has been noted (Postma \& Lengeler, 1985; Saier, 1985). We were unable to detect an accumulation of sucrose phosphate. However, previous workers were only able to detect the sucrose phosphate intermediate in mutants of Streptococcus mutans which lacked sucrose phosphate hydrolase (St Martin \& Wittenberger, 1979).

The lack of significant PEP-dependent phosphorylation of xylose (Table 1) indicated that an active transport mechanism was probably used. ATP-dependent phosphorylation was not detected either, but the absence may have been due to the equilibrium between xylose and xylulose. Xylose isomerase favours xylose formation by a factor of 6.25 (Barman, 1969). In general, pentoses are not transported by the PTS, but pentitol-specific PTSs have been observed in Lactobacillus casei (London \& Chase, 1977, 1979; London \& Hausman, 1982). It is well established that transmembrane gradients of protons or other ions can drive nutrient uptake. When intact cells of $S$. ruminantium HD4 were assayed for xylose uptake, significant inhibition $(83 \%)$ was measured in the presence of CCCP. This indicated that proton gradients may be involved in the transport of xylose. Lam et al. (1980) reported that the transport of xylose into Escherichia coli was by a p.m.f.-driven mechanism.

CCCP also caused some inhibition of glucose, maltose and sucrose uptake by whole cells (data not shown), but these results alone are not conclusive proof for active transport. Membrane 


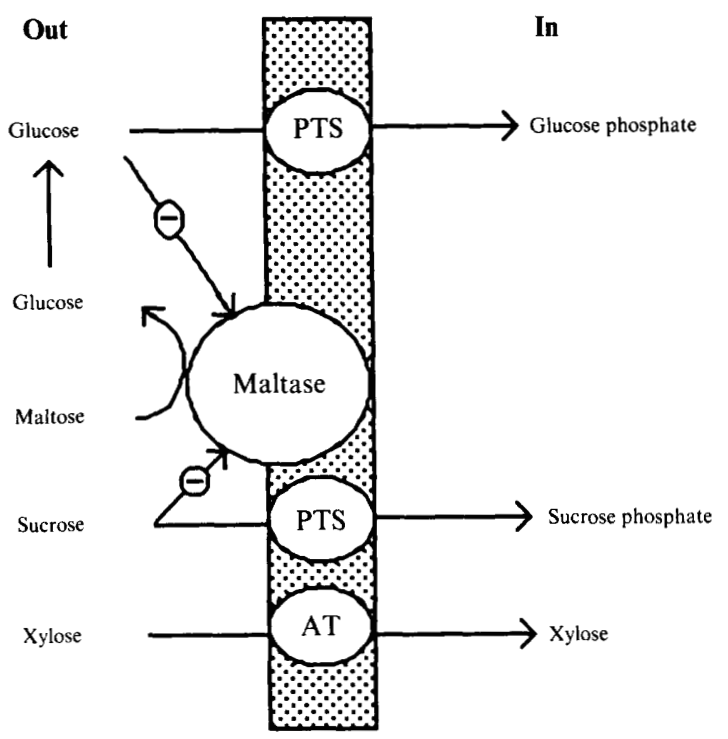

Fig. 1. Probable mechanisms of soluble carbohydrate transport by $S$. ruminantium. PTS, phosphoenolpyruvate phosphotransferase system; AT, active transport.

vesicle studies will be necessary to determine if these sugars are also actively transported. Chlorhexidine, a compound previously reported to be a 'specific' PTS inhibitor (Keevil et al., 1984; Marsh et al., 1983, 1984), inhibited the uptake of all four sugars by approximately $90 \%$. Since xylose did not appear to be taken up by a PTS, chlorhexidine is probably not a 'specific' PTS inhibitor. Chlorhexidine can also inhibit membrane-bound ATPases and affect membrane permeability (Harold et al., 1969; Sissons \& Midgley, 1981).

Probable mechanisms of sugar transport by $S$. ruminantium HD4 are shown in Fig. 1. Glucose and sucrose appeared to be phosphorylated by separate PTS components. Maltose was hydrolysed by an extracellular maltase and resulting glucose could then be transported by the constitutive glucose PTS. Since maltase activity was competitively inhibited by glucose and sucrose, glucose and sucrose can be used in preference to maltose. Some sucrase activity was detected, but this activity was much less than the maltase activity and approximately one-third the activity of the sucrose PTS. While small amounts of sucrose may also be hydrolysed extracellularly, most of the sucrose appears to be transported by a sucrose-specific PTS. Xylose was not phosphorylated by PEP, but its uptake was strongly inhibited by CCCP, a protonophore which interferes with active transport.

S.A.M. was supported by a graduate research fellowship provided by International Minerals Corp., Terre Haute, Ind. J. B. R. is a member of the US Dairy Forage Research Center, Madison, Wis.

\section{REFERENCES}

BARMAN, T. E. (1969). Enzyme handbook, vols 1 \& 2. New York: Springer Verlag.

BRADFORD, M. (1976). Photometric methods for protein determination. Procedures and materials. Analytical Biochemistry 72, 248-254.

BRYANT, M. P. (1956). The characteristics of strains of Selenomonas isolated from bovine rumen contents. Journal of Bacteriology 72, 162-167.

Counotte, G. H. M., Prins, R. A., Janssen, R. H. A. M. \& DE BIE, M. J. A. (1981). The role of Megasphaera elsdenii in the fermentation of $\mathrm{DL}-\left[2-{ }^{14} \mathrm{C}\right]$ lactate in the rumen of dairy cattle. Applied and Environmental Microbiology 42, 649-655.

DAHLQVIST, A. (1964). Method for assay of intestinal disaccharidases. Analytical Biochemistry 7, 18-25.

GACHELIN, G. (1970). Studies on the $\alpha$-methylglucoside permease of Escherichia coli. A two-step mechanism for the accumulation of $\alpha$-methylglucoside-6-phosphate. European Journal of Biochemistry 16, 342-357.

Groleau, D. \& Forsberg, C. W. (1981). Cellulolytic activity of the rumen bacterium Bacteroides succinogenes. Canadian Journal of Microbiology 27, 517-530. 
Harold, F. M., BaARda, J. R., Baron, C. \& ABRAMS, A. (1969). Dio 9 and chlorhexidine: inhibitors of membrane-bound ATPase and of cation transport in Streptococcus faecalis. Biochimica et biophysica acta 183, 129-136.

Hobson, P. N. (1965). Continuous culture of some anaerobic and facultatively anaerobic rumen bacteria. Journal of General Microbiology 38, 167-180.

Hungate, R. E. (1966). The Rumen and its Microbes. New York: Academic Press.

Keevil, C. W., Williamson, M. I., Marsh, P. D. \& Ellwood, D. C. (1984). Evidence that glucose and sucrose uptake in oral streptococcal bacteria involves independent phosphotransferase and protonmotive force-mediated mechanisms. Archives of Oral Biology 29, 871-878.

Kesters-Hilderson, H., Claeyssens, M., Van Doorslaer, E., Samen, E. \& De Bruyne, D. K. (1982). $\beta$-Xylosidase from Bacillus pumilus. Methods in Enzymology 83, 631-639.

Kornberg, H. L. \& Reeves, R. E. (1972). Inducible phosphoenolpyruvate-dependent hexose phosphotransferase activities in Escherichia coli. Biochemical Journal 128, 1339-1344.

LaM. V. M. S., Daruwalla, K. R., Henderson, P. J. F. \& Jones-Mortimer, M. C. (1980). Protonlinked D-xylose transport in Escherichia coli. Journal of Bacteriology 143, 396-402.

Latham, M. J., Sharpe, M. E. \& Sutton, J. D. (1971). The microbial flora of the rumen of cows fed hay and high cereal rations and its relationship to the rumen fermentation. Journal of Applied Bacteriology 34, 425-434.

LESSEL, E. R., JR \& BREED, R. S. (1954). Selenomonas Boskamp, 1922 - a genus that includes species showing an unusual type of flagellation. Bacteriological Reviews 18, 165-169.

London, J. \& ChaSE, N. M. (1977). New pathway for the metabolism of pentitols. Proceedings of the National Academy of Sciences of the United States of America 74, 4296-4300.

London, J. \& Chase, N. M. (1979). Pentitol metabolism in Lactobacillus casei. Journal of Bacteriology 140, 949-954.

London, J. \& Hausman, S. (1982). Xylitol-mediated transient inhibition of ribitol utilization by Lactobacillus casei. Journal of Bacteriology 150, 657-661.

Marsh, P. D., Keevil, C. W., MCDermid, A. S., Williamson, M. I. \& Ellwood, D. C. (1983). Inhibition by the antimicrobial agent chlorhexidine of acid production and sugar transport in oral streptococcal bacteria. Archives of Oral Biology 28, 233-240.

Marsh, P. D., Keevil, C. W. \& Ellwood, D. C. (1984). Relationship of bioenergetic processes to the pathogenic properties of oral bacteria. Journal of Dental Research 63, 401-406.

Martin, S. A. \& Russell, J. B. (1986). Phosphoenolpyruvate-dependent phosphorylation of hexoses by ruminal bacteria: evidence for the phosphotransferase transport system. Applied and Environmental Microbiology 52, 1348-1352.
Martin, S. A. \& Russell, J. B. (1987). Transport and phosphorylation of disaccharides by the ruminal bacterium Streptococcus bovis. Applied and Environmental Microbiology 53, 2388-2393.

Matin, A. \& VeldKaMP, H. (1978). Physiological basis of the selective advantage of a Spirillum $\mathrm{sp}$. in a carbon-limited environment. Journal of General Microbiology 105, 187-197.

Postma, P. W. \& Lengeler, J. W. (1985). Phosphoenolpyruvate : carbohydrate phosphotransferase system of bacteria. Microbiological Reviews 49, 232-269.

Robinson, I. M., Allison, M. J. \& Buchlin, J. A. (1981). Characterization of the cecal bacteria of normal pigs. Applied and Environmental Microbiology 41, 950-955.

Romano, A. H., Trifone, J. D. \& Brustolon, M. (1979). Distribution of the phosphoenolpyruvate: glucose phosphotransferase system in fermentative bacteria. Journal of Bacteriology 139, 93-97.

Russell, J. B. \& BALDWIN, R. L. (1978). Substrate preferences in rumen bacteria : evidence of catabolite regulatory mechanisms. Applied and Environmental Microbiology 36, 319-329.

Russell, J. B. \& Baldwin, R. L. (1979). Comparison of substrate affinities among several rumen bacteria: a possible determinant of rumen bacterial competition. Applied and Environmental Microbiology 37, 531-536.

Russell, J. B. \& Dombrowski, D. B. (1980). Effect of $\mathrm{pH}$ on the efficiency of growth by pure cultures of rumen bacteria in continuous culture. Applied and Environmental Microbiology 39, 604-610.

SAIER, M. H., JR (1985). Mechanisms and Regulation of Carbohydrate Transport in Bacteria. New York: Academic Press.

Scheifinger, C. C., Latham, M. J. \& Wolin, M. J. (1975). Relationship of lactate dehydrogenase specificity and growth rate to lactate metabolism by Selenomonas ruminantium. Applied and Environmental Microbiology 30, 916-921.

SEgel, I. H. (1976). Biochemical Calculations, 2nd edn, pp. 248-252. New York: John Wiley.

Sissons, A. \& Midgley, M. (1981). Energy transduction in Chlorobium limicola: role of membrane-bound adenosine triphosphatase and the proton electrochemical gradient. Journal of General Microbiology 122, 211-216.

St Martin, E. J. \& Wittenberger, C. L. (1979). Characterization of a phosphoenolpyruvate-dependent sucrose phosphotransferase system in Streptococcus mutans. Infection and Immunity 24, 865-868.

VADEboncoeur, C. \& Trahan, L. (1982). Glucose transport in Streptococcus salivarius. Evidence for the presence of a distinct phosphoenolpyruvate :glucose phosphotransferase system which catalyses the phosphorylation of $\alpha$-methylglucoside. Canadian Journal of Microbiology 28, 190-199.

Vadeboncoeur, C., Proulx, M. \& Trahan, L. (1983). Purification of proteins similar to HPr and enzyme I from the oral bacterium Streptococcus salivarius. Biochemical and immunochemical properties. Canadian Journal of Microbiology 29, 1694-1705. 